\title{
The Model of Bahasa Indonesia Teaching Materials Taken from Stories in Quran Taught with Content and Language Integrated Learning Approach
}

\author{
Izzah Izzah \\ Universitas Sriwijaya Palembang, \\ Indonesia \\ Email: izzahzen@fkip.unsri.ac.id
}

\author{
Zainal Rafli \\ Universitas Negeri Jakarta, \\ Indonesia \\ Email: zainal.rafli@unj.ac.id
}

\author{
Sakura Ridwan \\ Universitas Sriwijaya \\ Palembang, Indonesia
}

Received: 20 December 2017. Revised: 11 March 2018. Accepted: 10 April 2018

\begin{abstract}
This research aims to develop model of Bahasa Indonesia teaching materials which are taken from stories in Quran by using Content and Language Integrated Learning (CLIL)approach in grade 7 of Madrasah Tsanawiyah Muqimus Sunnah Palembang. Research method employed in this study is Research and Development (R\&D). The research procedure undertaken in this study is taken from theory of Borg and Gall that consists of three steps, i.e. introduction, development, and evaluation. Meanwhile, for the data collection technique, this study implements documentation, observation, questionnaire, interview, and test. As for the validity and reliability of the model of teaching materials in this study, researchers ask for assessment and evaluation from experts, i.e. the syllabus expert, Bahasa Indonesia expert, and Islamic religion expert. The result shows that the teaching material model is effective and eligible to be used. The highest score of the experimental class is 95 and the lowest score is 74 , while the average score is 87 . Meanwhile, the highest and lowest score of the control class are 84 and 64, respectively, with average score of 77.5. Moreover, the average score between the experimental and control group also has been tested and counted by using t-test and shows a significant result, that ist $\mathrm{count}_{\text {t }}=5.34>\mathrm{t}_{\text {table }}=1.685$.
\end{abstract}

Keywords: Teaching materials model, stories in Quran, and CLIL

How to Cite: Izzah, I., Rafli, Z., \& Ridwan, S. (2018). The Model of bahasa Indonesia teaching materials taken from stories in Quran taught with content and language integrated learning approach. Language Circle: Journal of Language and Literature, 12(2), 123-142.

\section{Introduction}

The existence of teaching materials as a media to achieve learning goals is very important. Therefore, teacher needs to provide and develop the teaching materials, so that the learning goals as stated in the curriculum can be achieved. A teaching material needs to have a good quality and "close" to the students' life (Atmazaki et al., 2017, p.58). Therefore, in 2013 curriculum that uses text as the basic of learning, the text-based teaching materials need to be selected carefully based on the need and interest of the students.

The existence of teaching materials, like, textbook, is considerably needed to support the learning effectiveness (Purnomo, et al., 2015, p.119). However, finding teaching materials which integrate four components of the 2013 curriculum's core competence that suits the students' interest 
and need is a tricky process (Kurniasih and Berlin, 2013, p.151).

From the preliminary research's observation and interview, it was found that Bahasa Indonesia teachers in Madrasah Tsanawiyahuse the textbook published by Erlangga press, Jakarta (Nurhadi \& Yuni, 2017). From the sample of the textbook, it was found that the book has already described the core competence 2, 3, and 4. However, the spiritual competence is not shown yet. Teachers claim that finding teaching materials that contains texts with religious value in it is hard, except for the texts used in religion lesson.

Besides what already had been discussed above, through the interview of two Bahasa Indonesia teachers in Madrasah Tsanawiyah Muqimus Sunnah Palembang, it is found that the teaching materials that are used today tend to develop the competence that have been separated, not integrated, and not holistic. Moreover, the current teaching materials are also considered not appropriate with the need of the school which is under the Ministry of Religion. It also does not support the objective of social, knowledge, and skills competence in integrated way (interview result on October 1, 2015).

From the test results point of view, the average score of National examination for Bahasa Indonesia subject in this school is 71.73. This score is still below the target of Minimum Mastery Criteria or in Indonesia is called as Kriteria Ketuntasan Minimal (KKM) for Bahasa Indonesia subject, that is 75.00 (interview with the head of MTs Muqimus Sunnah). In addition, from the process, the average score of grade 7 students' daily test are 79. It is already above the score target that had been set. However, Bahasa Indonesia teachers still feel unsatisfied since they believe that the teaching materials they use are still lack in number and quality in order to achieve the target competence.

In order to achieve the integratedaspects such as spiritual/ religious, social, knowledge competence, and skills competence, the researcher designs and creates texts for Bahasa Indonesia teaching materials. The teaching materials are taken from stories in Quran. There are plenty of stories in the Quran that can be cited as teaching materials for students to learn Bahasa Indonesia. Here, folklore and short story are already considered enough to be used as the sources of Bahasa Indonesia teaching and learning since it can sharpen the feeling, logic, imagination, and sensitivity of the students (Hidayati, 2014, p. 123).

Based on that consideration, it is seen that a research on Bahasa Indonesia teaching materials is needed to be done under the Research and Development study design. Model of teaching materials which is developed here is allbased on stories taken from the Quran with Content and Language Integrated Learning or CLIL as the study approach. CLIL is selected as the study approach since it is seen to be able to improve the language competence as well as some other competences. The CLIL approach itself is a learning concept which combines language and content in the learning process (Nurkhin, 2014, p.145).

Other considerations of using CLIL as the approach are, first, language learning should be integrated. It means that people who learn language cannot just select one of the language skills to be learnt but they need to master all the skills in integrated way (Alimi, 2013). Second, texts which are used as the learning sources are supposed to be interrelated with the other learning subjects to make the learning more fruitful with some variations, more interesting, and more 
integrated. Third is the tendency of teachers to avoid teaching literary materials. Thus, the CLIL approach in this study is seen to be suitable for the purpose of the study since it can mix the language learning with literature inintegrative and fun way.

This research is focused on the development of Bahasa Indonesia teaching materials which are taken from the stories of Quran for students of Madrasah Tsanawiyah Muqimus Sunnah Palembang by using the approach of Content and Language Integrated Learning (CLIL).

The sub-focuses of this research are, as follows:

1) Identification of Bahasa Indonesia teaching materials which are appropriate with the need of students and teachers in Madrasah Tsanawiyah Muqimus Sunnah Palembang.

2) The current condition of Bahasa Indonesia teaching materials used in Madrasah Tsanawiyah Muqimus Sunnah Palembang.

3) The design of Bahasa Indonesia learning materials model which is taken from Quran'sstories using the approach of CLIL that is suitable with the need of the students and teachers in Madrasah Tsanawiyah Muqimus Sunnah Palembang.

4) The model appropriateness from the development result of Bahasa Indonesia teaching materials which are taken from QuranwithCLIL approach.

5) Perception of the user related to Bahasa Indonesia teaching materials which are taken from Quran stories with CLIL approach.

6) The effectiveness of development result of Bahasa Indonesia teaching materials

The results of this study are expected to provide theoretical and practical benefits in the form of thought contribution in teaching materials alternative that can be considered as the effort to fix the quality of education, especially learning quality of Bahasa Indonesia in the Junior High School or Madrasah Tsanawiyah and the equal school level.

\section{Literature Review \\ Definition of Model}

Model is an imitation of a real condition to represent a reality. The important role of a model is to help one to understand and interpret certain phenomena or a reality. Model is also defined as a representation of the essential aspects of an exciting system (or a system to be constructed) which presents knowledge of that system in usable form (Verspoor, et al., 2011, pp. 99-100).

In line with this is Rusman (2014, pp. 132-133) who stated that model is a pattern that is based on certain theories, principles and considerations. According to Suparman (2014, pp. 106-107), model is a word that is used to explainvarious concepts since it is matched with the contexts that will be drawn.

Model Research and Development is the substance of a bigger Research and Development (R\&D) which is used to produce a specific product. Borg and Gall stated that "What is research and delevopment? it is a process used to develop and validate educational product". It means that Research and Development is a process that is used to validate and develop product (Sugiyono, 2015).

In addition, Gay, Mills, \& Airasian (2012) stated that "it results in quality products designed to meet specific educational needs". This Research and Development is designed to produce qualify products to fulfill the need. Graves (2000) explained that the development of teaching materials is a planning process that expect a teacher, lecturer, instructor, or tutor to 
produce learning units by delivering the general and specific goals in learning process. The teaching materials development means to create, select, adjust, and compile the materials and activities. Therefore, the students can reach the goals that will help them to reach the learning objectives.

\section{Research and Development Models}

There are some model development designs that can be used to design and develop the learning process, i.e. a) The Procedure and Development of Instructional System Model (PPSI), b) The Glasser Model, c) The Gearlach\& Ely Model, d) The Jerold E. Kemp Model (Rusman, 2014), e) The Dick and Carey Model (Dick and Carey, 2009), f) The ADDIE model (Tegeh, et al., 2014), and g) The Borg and Gall Model (Borg and Meredith, 1983). Those seven research and development models have similar general character which is the existence of need analysis, design, development, implementation, and evaluation.

\section{Language Teaching Materials Model}

Teaching material consists of two words; teaching and material. Those are used to helpteacher/ instructor in doing the learning activities. This material can be in a written or unwritten form. Brown categorizes kinds of classroom teaching materials as the textbook, audio and visual program, games, or various kinds of activities that are used in the class during the teaching an $\mathrm{d}$ learning process.

Teaching material components consist of two things, which are (1) language knowledge that includes (a) phonology, (b) morphology, (c) syntax, (d) semantic, and (2) language skills including, comprising, (a) listening, (b) speaking, (c) reading, (d) writing. In addition, there are also literary materials included in the components,like, poetry, prose, and drama. This teaching material should also be equipped with cultural materials encompassing national and international culture. In addition to the mentioned components is the stories taken from Quran that will become the basis of each theme of the teaching materials.

This research employs three development models. Those are Tomlinson (Tomlinson, 2011), Brown (Brown, 2014), as well as Jolly and Bolitho (Jolly and Rod, 2011). Thus, the steps undertaken in this study are 1) curriculum, 2) need analysis, 3) syllabus, 4) text collection, 5) text selection, 6) material creation, 7) piloting (trial and error), and 8) evaluation and revision.

\section{Content and Language Integrated Learning} (CLIL)

Content and Language Integrated Learning (CLIL) is an integrated language and content learning (Cambridge English). Through this approach, students obtain two benefits; gaining the knowledge and understanding the specific learning subject as well as learning target language. Coyle et al. confirmed that CLIL is highly relevant to the current learning situation. According to them, CLIL does not only teach the language to the learner, but also integratethe language with other subjects. Further, CLIL also teaches about culture of the language that is taught, and not to mention is the current global culture (Coyle, et al., 2010, pp. 9-10).

Coyle (as cited in Cross \& Gearon) stated that there are four core things in CLIL, those are culture, communication, content, and cognition as illustrated in Figure 1. 


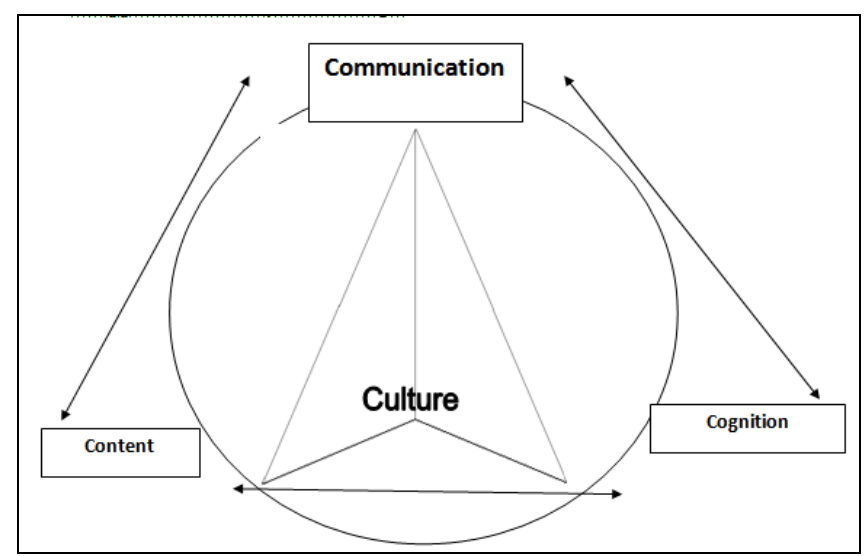

Figure 1 The Concept of CLIL

\section{Stories in Quran}

Quran is a revelation of Allah that was revealed to the Prophet Muhammad through the angel Gabriel to be conveyed to human. According to general calculations, the number of verses in the Quran are 6,236, consisting of 114 letters. Quran is the most unique and characteristic holy book (Ismail, 2013).

Based on Zaman (2014), 2013 curriculum has already had spiritual value. However, the implementation is still far from the initial objectives. For example, in science lesson, it is formulated that by learning science, students will have more faith to Allah. The lack of the mentioned learning objectives is that there is no single scientist who is willing to create teaching materials to actualize the objective as stated before.

In Quran (HAMKA, 2015), Allah stated, "We send you the best story" (Yusuf: $3)$. Stories in Quran consist of 1600 verses. Those stories will become a media to convey value and learning objectives. Allah says about the importance of the stories;

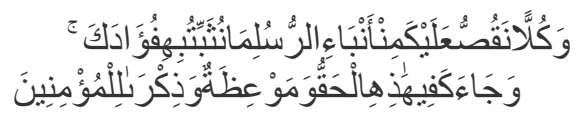

'There is a lesson in these stories of former people for the men of common sense. This story revealed in the Qur'an is not an invented tale, but a confirmation of previous scriptures - a detailed exposition of all things, and is a guidance and blessing for the people who believe. (Yusuf: 111).

An Nahlawi adds that in addition to the use of command and prohibition in conveying the message, Quran also uses stories, such as those contained in Al-Anbiya', Al-Qashash, Yusuf, and Noah. According to Mansur, the story has a great role in influencing the human soul. In addition, stories can guide good behavior and little by little can improve bad behavior. In short, the story is an effective tool in education. Aziz added that not only stimulating the intellectual aspect, but a story can also stimulate sensitivity, subtlety, emotion, art, fantasy, and imagination.It can even activate the left brain and right brain at once (Subur, 2015, pp. 7577).

\section{Methodology}

The aim of this research is to produce teaching materials model of Bahasa Indonesia which is taken from stories in Quran by using 
CLIL approach for grade 7 at Madrasah Tsanawiyah Muqimus Sunnah Palembang.

This research is held in Madrasah Tsanawiyah Muqimus Sunnah that is under Islamic Boarding School Muqimus Sunnah, Departen Lama Street, number 147, 27 Ilir, Palembang. This research was done in Desember 2015 until August 2017.

This research is using mix-method which combines qualitative and quantitative study designs. Method that is implemented in the study is Research and Development ( $R$ and D) (Sugiyono, 2015; Ali and Muhammad, 2014; Putra, 2014). Data collection techniques employed are (1) documentation, (2) observation, (3) questionnaire (Nation and John Macalister, 2010), (4) interview, and (5) test.

\section{Results and Discussion Identification of Learning Materials Need} In order to understand the need of students and teachers towards Bahasa Indonesia teaching material in grade 7 , researchers distribute questionnaires to Bahasa Indonesia subject's students and teachers. Students who were given this questionnaire were students of Madrasah Tsanawiyah class before year 2017/2018, those were students of class 2014/2015 and 2015/2016.

The following is the presentation of data analysis recapitulation of teaching materials need, either by teachers or based on student opinions. The full table is presented as follows.

Table 1 Average Recapitulation of Teaching Materials Need (Teacher and Student)

\begin{tabular}{|l|c|c|c|c|}
\hline Needs & Teacher & Student & Average & Category \\
\hline Theme & 3.08 & 2.98 & 3.03 & Needed \\
\hline Listening & 3.39 & 3.01 & 3.2 & Needed \\
\hline Speaking & 3.46 & 3.02 & 3.24 & Needed \\
\hline Reading & 3.05 & 2.96 & 3.005 & Needed \\
\hline Writing & 2.93 & 2.93 & 2.93 & Needed \\
\hline Literature Material & 3.33 & 3.17 & 3.25 & Needed \\
\hline Cultural Material & 3.43 & 2.87 & 3.15 & Needed \\
\hline $\begin{array}{l}\text { Tasks / Exercises based on the } \\
\text { number of students }\end{array}$ & 3.58 & 3.17 & 3.375 & Very needed \\
\hline Tasks/ Exercises & 3.4 & 3.07 & 3.235 & Needed \\
\hline Types of Tasks/ Exercises & 3.17 & 3.21 & 3.19 & Needed \\
\hline Evaluation Material & 3.5 & 3.08 & 3.29 & Very needed \\
\hline Evaluation Types & 3.58 & 3.23 & 3.405 & Very needed \\
\hline $\begin{array}{l}\text { Evaluation Based on Student } \\
\text { Numbers }\end{array}$ & 3.5 & 3.21 & 3.355 & Very needed \\
\hline Evaluation Form & 3.36 & 2.9 & 3.13 & Needed \\
\hline
\end{tabular}


Izzah, I., Rafli, Z., \& Ridwan, S. (2018). The Model of Bahasa Indonesia Teaching Materials Taken from Stories in Quran Taught with Content and Language Integrated Learning Approach. Language Circle: Journal of Language and Literature, 12(2), 123-142.

\section{The Teaching Materials Condition}

Based on the result of questionnaire analysis for teaching materials that is used by Bahasa Indonesia teacher, results are shown in Table 2.

Table 2 The Teaching Material Condition's Questionnaire Analysis

\begin{tabular}{|l|l|l|l|}
\hline No. & \multicolumn{1}{|c|}{ Statement } & Score & Category \\
\hline 1 & $\begin{array}{l}\text { Basic Development of BIPA teaching } \\
\text { materials }\end{array}$ & 1.13 & Not feasible/ replaced \\
\hline 2 & Objectives and Approach & 1.5 & Not feasible/ replaced \\
\hline 3 & $\begin{array}{l}\text { Design and Organization of Teaching } \\
\text { Materials }\end{array}$ & 1.32 & Not feasible/ replaced \\
\hline 4 & Language Skills Content & 1.31 & Not feasible/ replaced \\
\hline 5 & Language Content & 1.19 & Not feasible/ replaced \\
\hline 6 & Cultural Content & 1 & Not feasible/ replaced \\
\hline 7 & Theme/ Topic & 1.25 & Not feasible/ replaced \\
\hline 8 & Methodology & 1.29 & Not feasible/ replaced \\
\hline
\end{tabular}

From the table, it is known that the score for all statements areunder 2.0. It means that book that is used by the teacher is not match with CLIL standard and not basedon stories in Quran. Therefore, the learning process is not being integrated. In addition, core competence in Bahasa Indonesia learning process is not integrated yet between one and another.

\section{Design of the Developed Teaching Materials Model}

Based on the analysis results of the need that have been discussed before, the researcher created teaching materials, comprising (1) syllabus and (2) teaching materials. The textbook that is being designed comprises of: (1) student book and (2) teacher book. Design of the teaching materials is sourced from stories in Quran by and adapts CLIL as the approach. The scheme of teaching material book is illustrated in Figure 2. 


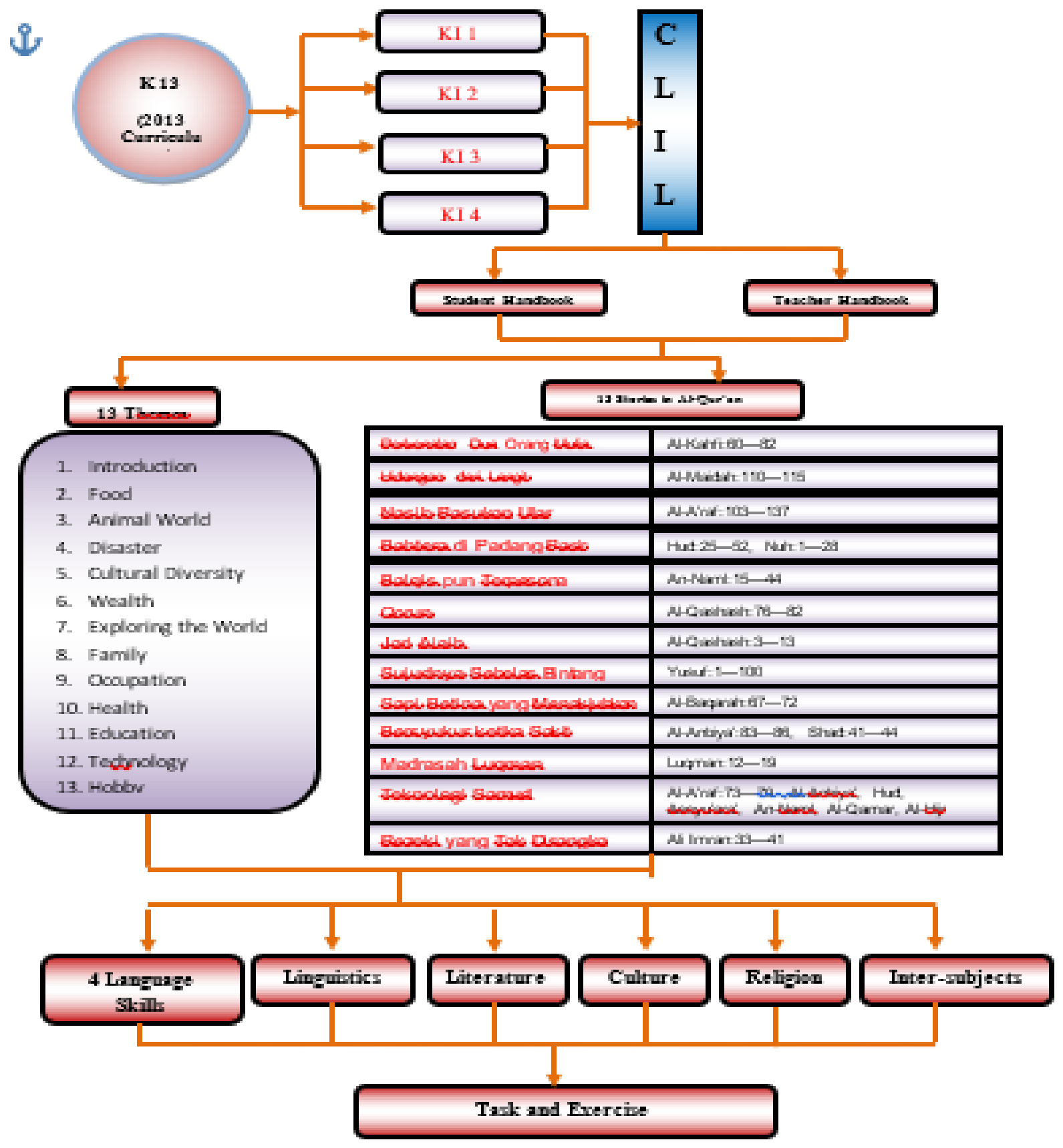

Notes:

K-13 : 2013 Curriculum

KI : Core Competence

Figure 2. Learning Material Model of Bahasa Indonesia Grade 7 (Draft 1) 
Feasibility of the Teaching Materials

\section{Regarding to the Experts}

There are six experts that score the validity and reliability of these teaching materials. Those six experts consist of (1) two syllabus experts, (2) two Bahasa Indonesia experts, (3) two Islam Religion experts. Below is the questionnaire analysis result from syllabus experts.

Table 3 Questionnaire Analysis Results of Syllabus Experts

\begin{tabular}{|c|c|c|c|c|c|}
\hline \multirow[t]{2}{*}{ No. } & \multirow[t]{2}{*}{ Syllabus Assessment Aspect } & \multicolumn{2}{|c|}{ Experts } & \multirow[t]{2}{*}{ Average } & \multirow[t]{2}{*}{ Note } \\
\hline & & 1 & 2 & & \\
\hline 1. & $\begin{array}{l}\text { The syllabus has been prepared with } \\
\text { reference to the needs of grade } 7 \\
\text { students. }\end{array}$ & 4 & 4 & 4 & $\begin{array}{l}\text { Very feasible / } \\
\text { maintained }\end{array}$ \\
\hline 2. & $\begin{array}{l}\text { The syllabus has been compiled based } \\
\text { on the CLIL reference frame }\end{array}$ & 4 & 4 & 4 & $\begin{array}{l}\text { Very feasible / } \\
\text { maintained }\end{array}$ \\
\hline 3. & $\begin{array}{l}\text { Core competence in the curriculum has } \\
\text { been in accordance with the } \\
\text { competencies to be achieved bygrade } 7 \\
\text { students }\end{array}$ & 4 & 4 & 4 & $\begin{array}{l}\text { Very feasible / } \\
\text { maintained }\end{array}$ \\
\hline 4. & $\begin{array}{l}\text { Basic competence in syllabus has been } \\
\text { in accordance with the competence that } \\
\text { can be achieved by Grade } 7 \text { students }\end{array}$ & 4 & 4 & 4 & $\begin{array}{l}\text { Very feasible / } \\
\text { maintained }\end{array}$ \\
\hline 5. & $\begin{array}{l}\text { The indicators in syllabus have been } \\
\text { match with competence and material for } \\
\text { students grade } 7\end{array}$ & 4 & 4 & 4 & $\begin{array}{l}\text { Very feasible / } \\
\text { maintained }\end{array}$ \\
\hline 6. & $\begin{array}{l}\text { Themes that are given in syllabus have } \\
\text { been matched with the need of grade } 7 \\
\text { students }\end{array}$ & 4 & 4 & 4 & $\begin{array}{l}\text { Very feasible / } \\
\text { maintained }\end{array}$ \\
\hline 7. & $\begin{array}{l}\text { Theme that is contained by the syllabus } \\
\text { have already varied }\end{array}$ & 4 & 4 & 4 & $\begin{array}{l}\text { Very feasible / } \\
\text { maintained }\end{array}$ \\
\hline 8. & $\begin{array}{l}\text { Listening material in syllabus match } \\
\text { with the need of Grade } 7 \text { student }\end{array}$ & 3 & 3 & 3 & $\begin{array}{l}\text { Feasible / } \\
\text { maintained }\end{array}$ \\
\hline 9. & $\begin{array}{l}\text { Speaking material in syllabus match } \\
\text { with the need of Grade } 7 \text { students }\end{array}$ & 3 & 4 & 3.5 & $\begin{array}{l}\text { Very feasible / } \\
\text { maintained }\end{array}$ \\
\hline 10. & $\begin{array}{l}\text { Reading material in syllabus match with } \\
\text { student need in grade } 7\end{array}$ & 3 & 4 & 3.5 & $\begin{array}{l}\text { Very feasible / } \\
\text { maintained }\end{array}$ \\
\hline 11. & $\begin{array}{l}\text { Writing material in syllabus match with } \\
\text { the need of grade } 7 \text { student }\end{array}$ & 3 & 4 & 3.5 & $\begin{array}{l}\text { Very feasible / } \\
\text { maintained }\end{array}$ \\
\hline 12. & $\begin{array}{l}\text { Grammar material on the syllabus } \\
\text { match with the need of Grade } 7 \\
\text { students }\end{array}$ & 3 & 4 & 3.5 & $\begin{array}{l}\text { Very feasible / } \\
\text { maintained }\end{array}$ \\
\hline 13. & $\begin{array}{l}\text { Cultural material on the syllabus match } \\
\text { with the need of Grade } 7 \text { students }\end{array}$ & 3 & 4 & 3.5 & $\begin{array}{l}\text { Very feasible / } \\
\text { maintained }\end{array}$ \\
\hline
\end{tabular}




\begin{tabular}{|c|l|c|c|c|l|}
\hline No. & \multicolumn{1}{|c|}{ Syllabus Assessment Aspect } & \multicolumn{2}{|c|}{ Experts } & Average & Note \\
\cline { 3 - 4 } & & $\mathbf{1}$ & $\mathbf{2}$ & & \\
\hline 14. & $\begin{array}{l}\text { Religion material on the syllabus match } \\
\text { with the need of Grade 7 students }\end{array}$ & 3 & 4 & 3.5 & $\begin{array}{l}\text { Very feasible / } \\
\text { maintained }\end{array}$ \\
\hline 15. & $\begin{array}{l}\text { The material on the syllabus has } \\
\text { integrated four language, grammatical, } \\
\text { cultural, and religious skills in a single } \\
\text { theme }\end{array}$ & 4 & 4 & 4 & $\begin{array}{l}\text { Very feasible / } \\
\text { maintained }\end{array}$ \\
\hline 16. & $\begin{array}{l}\text { The syllabus has been prepared by } \\
\text { giving the attention to the gradation } \\
\text { (degree of difficulty) of the material }\end{array}$ & 4 & 3 & 3.5 & $\begin{array}{l}\text { Very feasible / } \\
\text { maintained }\end{array}$ \\
\hline 17. & $\begin{array}{l}\text { The syllabus has been compiled } \\
\text { regarding to the order of the concrete } \\
\text { material to the abstract }\end{array}$ & 4 & 3 & 3.5 & $\begin{array}{l}\text { Very feasible / } \\
\text { maintained }\end{array}$ \\
\hline 18. & $\begin{array}{l}\text { The material listed on the syllabus has } \\
\text { fulfilled the principle of "learning a } \\
\text { language is learning to communicate }\end{array}$ & 3 & 4 & 3.5 & $\begin{array}{l}\text { Very feasible / } \\
\text { maintained }\end{array}$ \\
\hline 19. & $\begin{array}{l}\text { The time listed on the syllabus matches } \\
\text { the needs of teachers and students }\end{array}$ & 3 & 3 & 3 & $\begin{array}{l}\text { Feasible / } \\
\text { maintained }\end{array}$ \\
\hline
\end{tabular}

Furthermore, the assessment score from Indonesian experts and Islamic experts of the Bahasa Indonesia learning material is presented. The results of this score indicate that the learning materials of Bahasa Indonesia result of the development is indeed very feasible and maintained. Here is the table.

Table 4 Scoring Table of Indonesian Expert and Islamic Expert

\begin{tabular}{|c|l|c|c|c|c|c|l|}
\hline No & \multicolumn{1}{|c|}{$\begin{array}{c}\text { Learning Material Scoring } \\
\text { Aspects }\end{array}$} & \multicolumn{1}{|c|}{$\begin{array}{c}\text { Ever- } \\
\text { age }\end{array}$} & \multicolumn{1}{|c|}{ Notes } \\
\cline { 3 - 8 } & & 1 & 2 & 3 & 4 & \\
\hline 1. & $\begin{array}{l}\text { The available teaching materials } \\
\text { have been prepared with reference } \\
\text { to the needs of Grade 7 students. }\end{array}$ & 4 & 4 & 4 & 4 & 4 & $\begin{array}{l}\text { Very feasible/ } \\
\text { maintained }\end{array}$ \\
\hline 2. & $\begin{array}{l}\text { The available teaching materials } \\
\text { have been arranged in line with } \\
\text { CLIL references framework. }\end{array}$ & 4 & 4 & 4 & 4 & 4 & $\begin{array}{l}\text { Very feasible/ } \\
\text { maintained }\end{array}$ \\
\hline 3. & $\begin{array}{l}\text { Every unit in teaching material } \\
\text { have included competences that } \\
\text { want to be achieved. }\end{array}$ & 3 & 4 & 4 & 4 & 3.75 & $\begin{array}{l}\text { Very feasible/ } \\
\text { maintained }\end{array}$ \\
\hline 4. & $\begin{array}{l}\text { Bahasa Indonesia learning } \\
\text { material have been matched with } \\
\text { the competencies of Grade 7 }\end{array}$ & 3 & 4 & 4 & 4 & 3.75 & $\begin{array}{l}\text { Very feasible/ } \\
\text { maintained }\end{array}$ \\
\hline
\end{tabular}


Izzah, I., Rafli, Z., \& Ridwan, S. (2018). The Model of Bahasa Indonesia Teaching Materials Taken from Stories in Quran Taught with Content and Language Integrated Learning Approach. Language Circle: Journal of Language and Literature, 12(2), 123-142.

\begin{tabular}{|c|c|c|c|c|c|c|c|}
\hline \multirow[t]{2}{*}{ No } & \multirow{2}{*}{$\begin{array}{c}\text { Learning Material Scoring } \\
\text { Aspects }\end{array}$} & \multicolumn{4}{|c|}{ Expert } & \multirow{2}{*}{$\begin{array}{l}\text { Aver- } \\
\text { age }\end{array}$} & \multirow[t]{2}{*}{ Notes } \\
\hline & & 1 & 2 & 3 & 4 & & \\
\hline & students & & & & & & \\
\hline 5. & $\begin{array}{l}\text { Teaching material can be used to } \\
\text { achieve listening competency for } \\
\text { Grade } 7 \text { students }\end{array}$ & 4 & 4 & 4 & 4 & 4 & $\begin{array}{l}\text { Very feasible/ } \\
\text { maintained }\end{array}$ \\
\hline 6. & $\begin{array}{l}\text { Teaching material can be used to } \\
\text { achieve speaking competency for } \\
\text { Grade } 7 \text { students }\end{array}$ & 4 & 4 & 4 & 4 & 4 & $\begin{array}{l}\text { Very feasible/ } \\
\text { maintained }\end{array}$ \\
\hline 7. & $\begin{array}{l}\text { Teaching material can be used to } \\
\text { achieve skills competency for } \\
\text { Grade } 7 \text { students }\end{array}$ & 4 & 4 & 4 & 3 & 3.75 & $\begin{array}{l}\text { Very feasible/ } \\
\text { maintained }\end{array}$ \\
\hline 8. & $\begin{array}{l}\text { Teaching material can be used to } \\
\text { achieve writing competency for } \\
\text { Grade } 7 \text { students }\end{array}$ & 3 & 4 & 4 & 4 & 3.75 & $\begin{array}{l}\text { Very feasible/ } \\
\text { maintained }\end{array}$ \\
\hline 9. & $\begin{array}{l}\text { Teaching material is developed by } \\
\text { integrated four language skills, } \\
\text { grammar, culture, and religion in } \\
\text { one theme }\end{array}$ & 4 & 4 & 4 & 3 & 3.75 & $\begin{array}{l}\text { Very feasible/ } \\
\text { maintained }\end{array}$ \\
\hline 10 . & $\begin{array}{l}\text { The teaching materials have } \\
\text { included cognitive aspect, } \\
\text { affective, and psychomotor }\end{array}$ & 4 & 4 & 3 & 4 & 3.75 & $\begin{array}{l}\text { Very feasible/ } \\
\text { maintained }\end{array}$ \\
\hline 11. & $\begin{array}{l}\text { The themes that is presented in } \\
\text { teaching material is appropriate } \\
\text { for Grade } 7 \text { students }\end{array}$ & 3 & 4 & 4 & 4 & 3.75 & $\begin{array}{l}\text { Very feasible/ } \\
\text { maintained }\end{array}$ \\
\hline 12. & $\begin{array}{l}\text { Introduction theme is an } \\
\text { appropriate theme for Grade } 7 \\
\text { students }\end{array}$ & 4 & 4 & 4 & 4 & 4 & $\begin{array}{l}\text { Very feasible/ } \\
\text { maintained }\end{array}$ \\
\hline 13. & $\begin{array}{l}\text { Family is an appropriate theme } \\
\text { for Grade } 7 \text { students }\end{array}$ & 4 & 4 & 4 & 4 & 4 & $\begin{array}{l}\text { Very feasible/ } \\
\text { maintained }\end{array}$ \\
\hline 14. & $\begin{array}{l}\text { Hobby is an appropriate theme for } \\
\text { Grade } 7 \text { students }\end{array}$ & 4 & 4 & 4 & 3 & 3.75 & $\begin{array}{l}\text { Very feasible/ } \\
\text { maintained }\end{array}$ \\
\hline 15. & $\begin{array}{l}\text { Food an appropriate theme for } \\
\text { Grade } 7 \text { students }\end{array}$ & 4 & 4 & 3 & 4 & 3.75 & $\begin{array}{l}\text { Very feasible/ } \\
\text { maintained }\end{array}$ \\
\hline 16. & $\begin{array}{l}\text { Job is an appropriate theme for } \\
\text { Grade } 7 \text { students }\end{array}$ & 3 & 4 & 3 & 4 & 3.5 & $\begin{array}{l}\text { Very feasible/ } \\
\text { maintained }\end{array}$ \\
\hline 17. & $\begin{array}{l}\text { Wealth is an appropriate theme } \\
\text { for Grade } 7 \text { students }\end{array}$ & 4 & 4 & 4 & 4 & 4 & $\begin{array}{l}\text { Very feasible/ } \\
\text { maintained }\end{array}$ \\
\hline 18. & $\begin{array}{l}\text { Disaster is an appropriate theme } \\
\text { for Grade } 7 \text { students }\end{array}$ & 4 & 4 & 4 & 3 & 3.75 & $\begin{array}{l}\text { Very feasible/ } \\
\text { maintained }\end{array}$ \\
\hline 19. & $\begin{array}{l}\text { Health is an appropriate theme for } \\
\text { Grade } 7 \text { students }\end{array}$ & 4 & 4 & 3 & 4 & 3.75 & $\begin{array}{l}\text { Very feasible/ } \\
\text { maintained }\end{array}$ \\
\hline
\end{tabular}




\begin{tabular}{|c|c|c|c|c|c|c|c|}
\hline \multirow[t]{2}{*}{ No } & \multirow{2}{*}{$\begin{array}{c}\text { Learning Material Scoring } \\
\text { Aspects }\end{array}$} & \multicolumn{4}{|c|}{ Expert } & \multirow{2}{*}{$\begin{array}{l}\text { Aver- } \\
\text { age }\end{array}$} & \multirow[t]{2}{*}{ Notes } \\
\hline & & 1 & 2 & 3 & 4 & & \\
\hline 20. & $\begin{array}{l}\text { Family theme is an appropriate } \\
\text { theme for Grade } 7 \text { students }\end{array}$ & 4 & 4 & 3 & 4 & 3.75 & $\begin{array}{l}\text { Very feasible/ } \\
\text { maintained }\end{array}$ \\
\hline 21. & $\begin{array}{l}\text { Animal an appropriate theme for } \\
\text { Grade } 7 \text { students }\end{array}$ & 4 & 4 & 3 & 4 & 3.75 & $\begin{array}{l}\text { Very feasible/ } \\
\text { maintained }\end{array}$ \\
\hline 22. & $\begin{array}{l}\text { Education is an appropriate theme } \\
\text { for Grade } 7 \text { students }\end{array}$ & 4 & 4 & 4 & 4 & 4 & $\begin{array}{l}\text { Very feasible/ } \\
\text { maintained }\end{array}$ \\
\hline 23. & $\begin{array}{l}\text { Technology is an appropriate } \\
\text { theme for Grade } 7 \text { students }\end{array}$ & 4 & 4 & 4 & 3 & 3.75 & $\begin{array}{l}\text { Very feasible/ } \\
\text { maintained }\end{array}$ \\
\hline 24. & $\begin{array}{l}\text { Travelling around the world is an } \\
\text { appropriate theme for Grade } 7 \\
\text { students }\end{array}$ & 3 & 4 & 4 & 4 & 3.75 & $\begin{array}{l}\text { Very feasible/ } \\
\text { maintained }\end{array}$ \\
\hline 25. & $\begin{array}{l}\text { Teaching materials have been } \\
\text { arranged systematically by } \\
\text { considering gradation (material } \\
\text { difficulties level) }\end{array}$ & 3 & 4 & 3 & 4 & 3.5 & $\begin{array}{l}\text { Very feasible/ } \\
\text { maintained }\end{array}$ \\
\hline 26. & $\begin{array}{l}\text { Teaching materials have been } \\
\text { arranged by considering sequence } \\
\text { from concrete to abstract }\end{array}$ & 3 & 4 & 4 & 4 & 3.75 & $\begin{array}{l}\text { Very feasible/ } \\
\text { maintained }\end{array}$ \\
\hline 27. & $\begin{array}{l}\text { Teaching materials have been } \\
\text { arranged by considering sequence } \\
\text { from comprehensive to separated } \\
\text { one. }\end{array}$ & 3 & 4 & 3 & 3 & 3.25 & $\begin{array}{l}\text { Feasible/ } \\
\text { maintained }\end{array}$ \\
\hline 28. & $\begin{array}{l}\text { Teaching materials have been } \\
\text { arranged by integrated language } \\
\text { skills component, grammar, } \\
\text { culture, and religion }\end{array}$ & 3 & 4 & 3 & 4 & 3.5 & $\begin{array}{l}\text { Very feasible/ } \\
\text { maintained }\end{array}$ \\
\hline 29. & $\begin{array}{l}\text { Teaching materials have been } \\
\text { accommodated various Grade } 7 \\
\text { students' interest that provide } \\
\text { themes variety }\end{array}$ & 3 & 4 & 4 & 4 & 3.75 & $\begin{array}{l}\text { Very feasible/ } \\
\text { maintained }\end{array}$ \\
\hline 30. & $\begin{array}{l}\text { Teaching material have been } \\
\text { accommodated various Grade } 7 \\
\text { students' learning styles that } \\
\text { provide audio, visual, and } \\
\text { kinaesthetic }\end{array}$ & 3 & 4 & 3 & 4 & 3.5 & $\begin{array}{l}\text { Very feasible/ } \\
\text { maintained }\end{array}$ \\
\hline 31. & $\begin{array}{l}\text { Teaching material is equipped } \\
\text { with illustration, figure, diagram, } \\
\text { and table to help the students } \\
\text { understand the material }\end{array}$ & 4 & 4 & 4 & 4 & 4 & $\begin{array}{l}\text { Very feasible/ } \\
\text { maintained }\end{array}$ \\
\hline
\end{tabular}


Izzah, I., Rafli, Z., \& Ridwan, S. (2018). The Model of Bahasa Indonesia Teaching Materials Taken from Stories in Quran Taught with Content and Language Integrated Learning Approach. Language Circle: Journal of Language and Literature, 12(2), 123-142.

\begin{tabular}{|c|c|c|c|c|c|c|c|}
\hline \multirow[t]{2}{*}{ No } & \multirow{2}{*}{$\begin{array}{c}\text { Learning Material Scoring } \\
\text { Aspects }\end{array}$} & \multicolumn{4}{|c|}{ Expert } & \multirow{2}{*}{$\begin{array}{l}\text { Aver- } \\
\text { age }\end{array}$} & \multirow[t]{2}{*}{ Notes } \\
\hline & & 1 & 2 & 3 & 4 & & \\
\hline 32. & $\begin{array}{l}\text { Teaching material is equipped } \\
\text { with teacher guidelines }\end{array}$ & 4 & 4 & 4 & 3 & 3.75 & $\begin{array}{l}\text { Very feasible/ } \\
\text { maintained }\end{array}$ \\
\hline 33. & $\begin{array}{l}\text { The teaching materials have } \\
\text { integrated the phonological } \\
\text { material needed by Grade } 7 \\
\text { students }\end{array}$ & 3 & 4 & 3 & 4 & 3.5 & $\begin{array}{l}\text { Very feasible/ } \\
\text { maintained }\end{array}$ \\
\hline 34. & $\begin{array}{l}\text { The teaching materials have } \\
\text { integrated the morphological } \\
\text { material needed by the Grade } 7 \\
\text { students }\end{array}$ & 4 & 4 & 4 & 4 & 4 & $\begin{array}{l}\text { Very feasible/ } \\
\text { maintained }\end{array}$ \\
\hline 35. & $\begin{array}{l}\text { The teaching materials have } \\
\text { integrated the syntactic material } \\
\text { needed by the students of grade } \\
\text { VII }\end{array}$ & 4 & 4 & 4 & 4 & 4 & $\begin{array}{l}\text { Very feasible/ } \\
\text { maintained }\end{array}$ \\
\hline 36. & $\begin{array}{l}\text { Teaching materials have } \\
\text { integrated semantic materials that } \\
\text { are required by grade VII students }\end{array}$ & 3 & 4 & 4 & 4 & 3.75 & $\begin{array}{l}\text { Very feasible/ } \\
\text { maintained }\end{array}$ \\
\hline 37. & $\begin{array}{l}\text { Teaching materials that have been } \\
\text { made to meet the language } \\
\text { learning principle is learn to } \\
\text { communicate }\end{array}$ & 4 & 4 & 3 & 4 & 3.75 & $\begin{array}{l}\text { Very feasible/ } \\
\text { maintained }\end{array}$ \\
\hline 38. & $\begin{array}{l}\text { The level of difficulty in the } \\
\text { exercise and the task has been in } \\
\text { accordance with the ability of } \\
\text { Grade } 7 \text { students }\end{array}$ & 4 & 4 & 4 & 4 & 4 & $\begin{array}{l}\text { Very feasible/ } \\
\text { maintained }\end{array}$ \\
\hline 39. & $\begin{array}{l}\text { Task and exercise techniques have } \\
\text { varied in the form of individuals } \\
\text { and groups }\end{array}$ & 4 & 4 & 3 & 3 & 3.5 & $\begin{array}{l}\text { Very feasible/ } \\
\text { maintained }\end{array}$ \\
\hline 40. & $\begin{array}{l}\text { Teachers can sequence learning } \\
\text { materials flexibly }\end{array}$ & 4 & 4 & 4 & 4 & 4 & $\begin{array}{l}\text { Very feasible/ } \\
\text { maintained }\end{array}$ \\
\hline & Average & $\begin{array}{l}3.6 \\
5\end{array}$ & 4 & 3.6 & 3.8 & 3.76 & $\begin{array}{l}\text { Very feasible/ } \\
\text { maintained }\end{array}$ \\
\hline
\end{tabular}

Based on those two tables and some advices and suggestions from the six experts, draft 2 of Bahasa Indonesia teaching materials is produced as follows. 


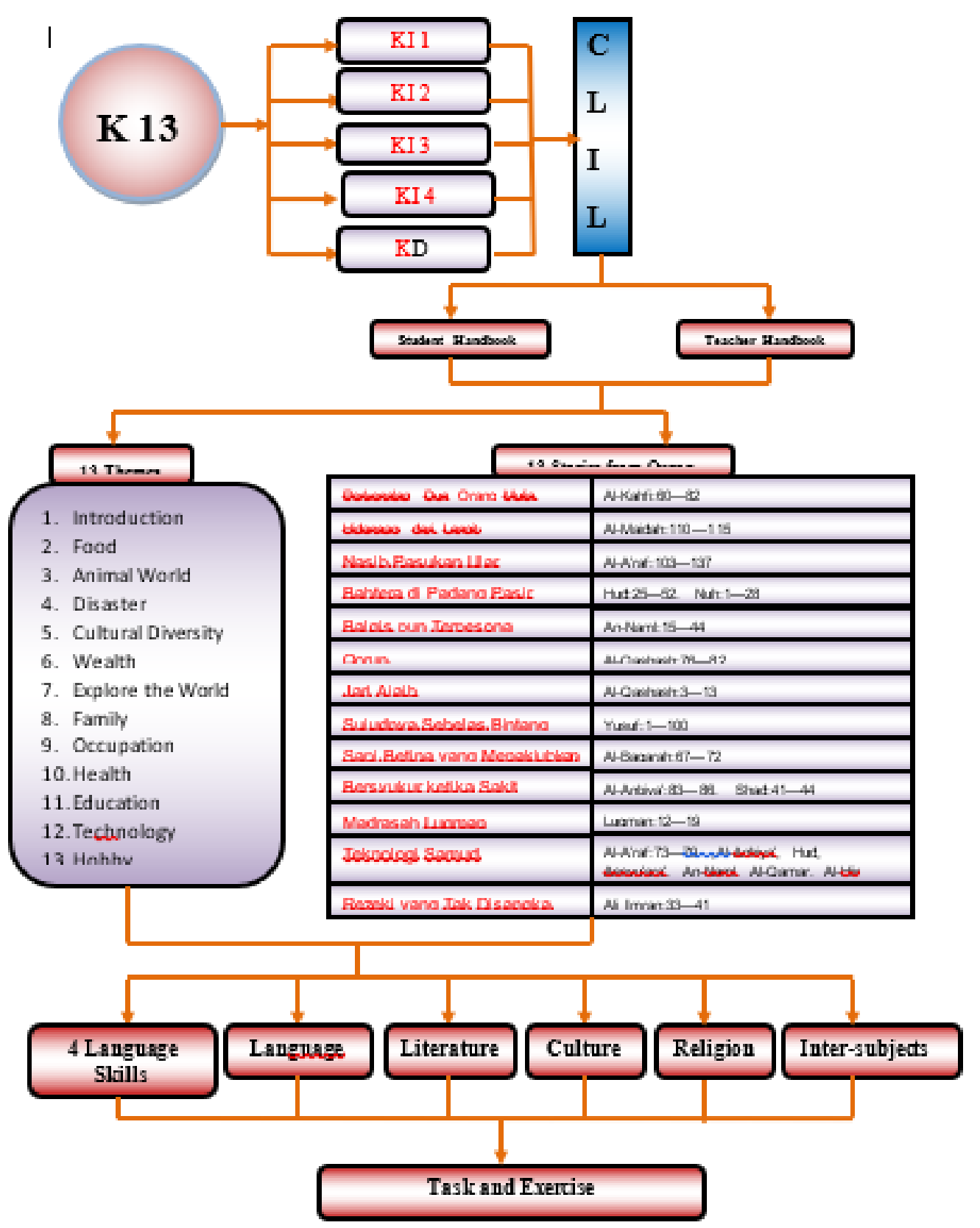

Notes:

K13 : 2013 Curriculum

KI : Core Competence

KD : Basic Competence

Figure 2: Draft 2 of Bahasa Indonesia Teaching Material Grade 7 


\section{The User Perception}

A limited trial was conducted for the Grade 7 students of Madrasah Tsanawiyah Muqimus Sunnah Palembang. The students of this class are chosen because they will be the ones who will use this resource. There were fifteen grade 7 students who are randomly selected to attend this limited trial. Here is a graph of the test result score.

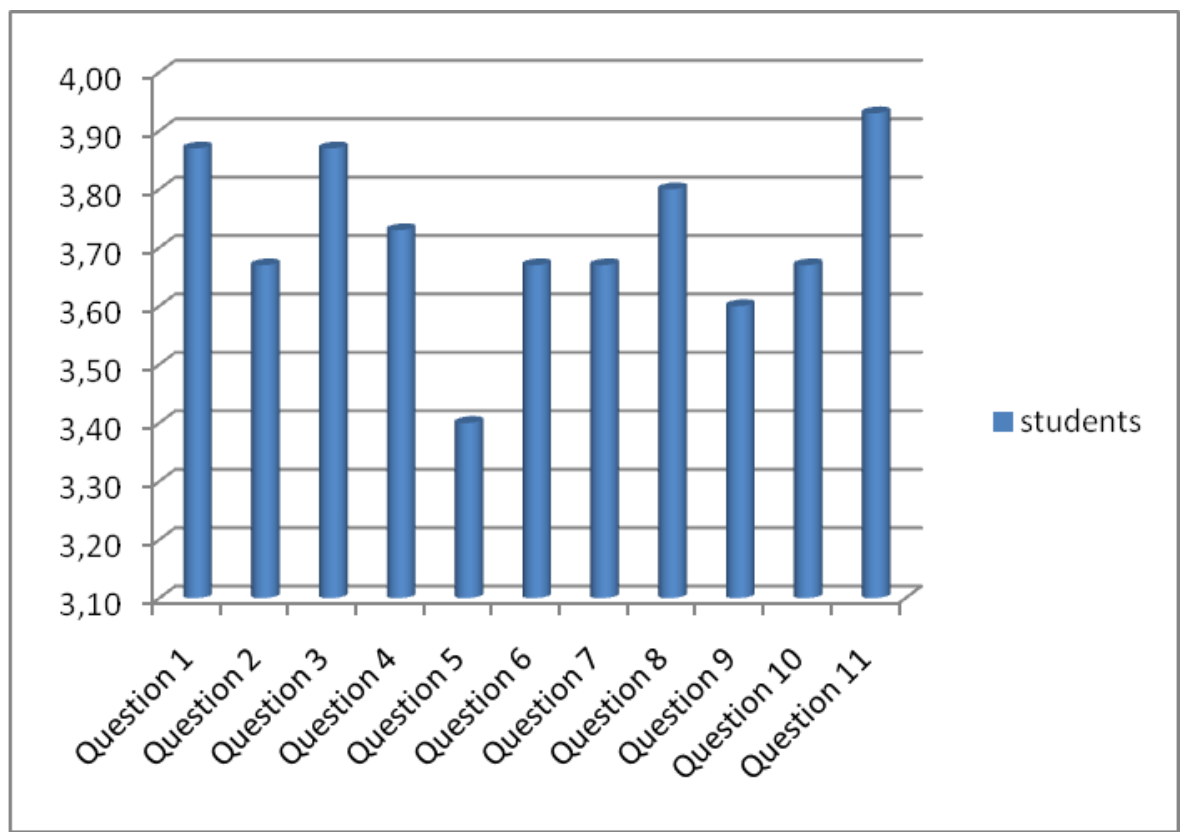

Figure 3 Graphic of Questionnaire Analysis of Students Perspectives toward the Development Research of Teaching Materials Model

Based on above tables and graphic, it is known that students perception scores towards teaching material from the development is on the average number of 3.72. It means that teaching materials as a result of this development is categorized as feasible to be maintained. Below is the figure of the $3^{\text {rd }}$ draft of teaching material after receiving some advices from the users. 


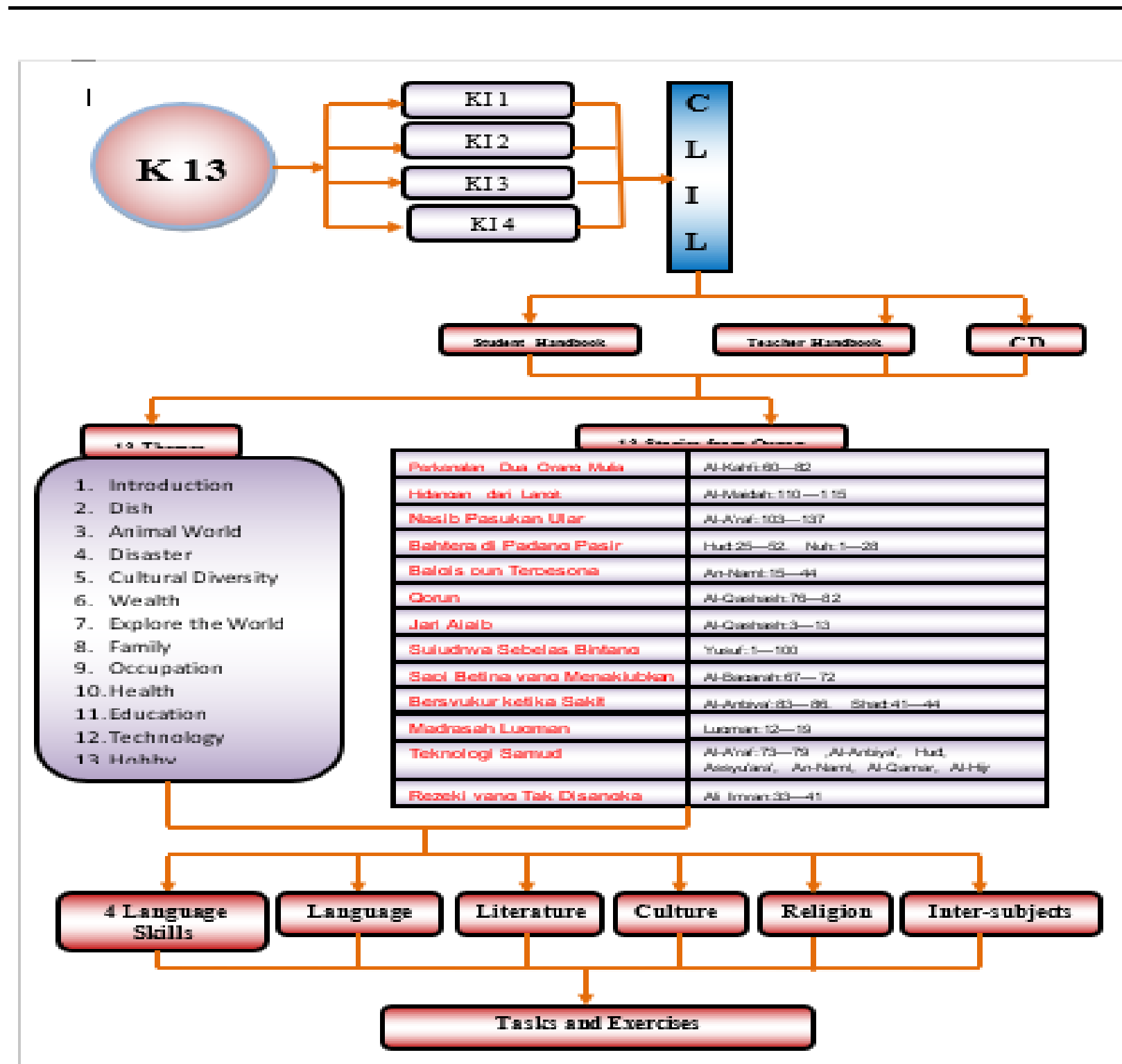

Note:

K13 : 2013 Curriculum

KI : Core Competences

Figure 4 Draft 3 of Teaching Material Model of Bahasa Indonesia Grade 7

\section{Effectiveness Model}

The last step of this research and development activity is to conduct experiments both in the experimental and control classes. Results of the research for the experimental class are the 95 for the highest score and 74 for the lowest score. The average value for the experimental class is 87 . Meanwhile, the post-test result for the control class is 84 as the highest score and the lowest score is 64 . The average value for the control class is 77.5. 
Izzah, I., Rafli, Z., \& Ridwan, S. (2018). The Model of Bahasa Indonesia Teaching Materials Taken from Stories in Quran Taught with Content and Language Integrated Learning Approach. Language Circle: Journal of Language and Literature, 12(2), 123-142.

After that, the t-Test results show that $\mathrm{t}_{\text {count }}=5.34>\mathrm{t}_{\text {table }}=1.685$. This means $\mathrm{H}_{\mathrm{o}}$ is rejected. Since $\mathrm{H}_{0}$ is rejected, then $\mathrm{H}_{i}$ is accepted. This means that the difference in both averages is significant. Thus, the average experiment class is higher than the control class with significant difference. It can be concluded that the model of learning materials of Bahasa Indonesia grade 7 which is derived from the stories in the Quran with CLIL approach is effective and can be used. The final model of Bahasa Indonesia teaching materials with CLIL approach is shown in Figure 5.

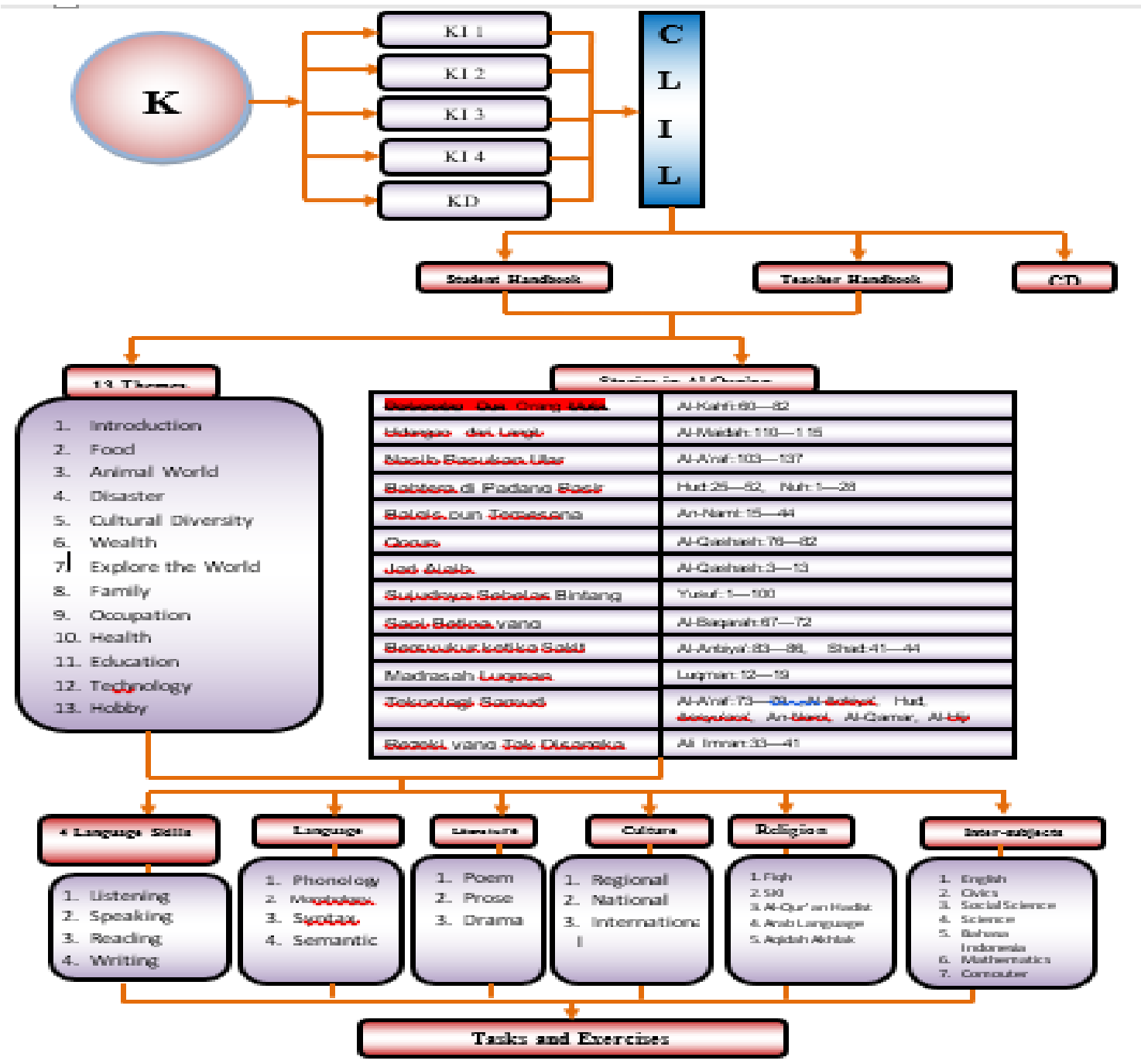

Note:

K13 : 2013 Curriculum

KI : Core Competence

KD : Basic Competence

Figure 5 Model of Grade 7's Bahasa Indonesia Teaching Material (Final Model) 


\section{Conclusion}

Based on the identification and the results of needs analysis, both teachers and students need teaching materials of Bahasa Indonesia taken from the stories in Quran with CLIL as the approach.

Based on the analysis of general picture about the condition of the teaching materials of Bahasa Indonesia forGrade 7, it can be concluded that (1) the syllabus used is not in accordance with the needs of teachers and students; (2) the student book used is also not in accordance with the CLIL standard; (3) there is no special grade 7 textbook for teachers; (4) there is no special CD to help learnersto do listening activities. The average score of teacher questionnaire analysis on the condition of the teaching materials used is 1.25. The average score is categorized as "unfeasible" or "must be replaced" as it is below 2.50.

Based on the design of teaching materials of Bahasa Indoneia for grade VII which is derived from the stories in the Quran with CLIL approach that has been in accordance with the needs of students and teachers, it has successfully developed (1) syllabus draft 1, (2) draft 1, 3syllabus draft 2, (4) drafting material 2, (5) syllabus draft 3,

(6) drafting material 3, (7) final syllabus, and

(8) final teaching materials. The development of one draft to the next draft has experienced process and evaluation phase in accordance with research and development procedures.

Based on the results of validation by six experts, the average score of curriculum experts and syllabus is 3.66. The average score of Bahasa Indonesia experts is 3.8. While the average score of Islamic religious experts is 3.7. In conclusion, the results of feasibility test of the teaching material model according to the three groups of experts are categorized very feasible because the average score is more than 3.25.

Based on the results of the assessment or perception of the users of the model of teaching materials that have been developed, the perception of users towards the subject is considerably high with the average score reached up to 3.71 .

Based on the results of test effectiveness, it is concluded that this model is proven to be effective. This is shown from the comparison of post-test results for the experimental class with the highest score of 95 and the lowest score of 74 . The average value for the experimental class is 87 . Meanwhile, the post-test result for the control class is 84 for the highest score and 64 for the lowest. Average value for the control class is 77.5. Meanwhile, the $\mathrm{t}$-test result is $\mathrm{t}_{\text {count }}=$ $5.34>\mathrm{t}_{\text {table }}=1.685$.

\section{References}

Ali, M., \& Asrori, M. (2014). Metodologi dan Aplikasi Riset Pendidikan. Jakarta: BumiAksara. Atmazaki, A., \& Zuve, F.O. (n.d.). Pengembangan Bahan Ajar Membaca Berbasis Konten. Retrieved from http:// www.conference.unsri.ac.id//index.php/SNBI/article/view/503/123.

Brown, H. D. (2007). Prinsip Pembelajaran dan Pengajaran Bahasa. Jakarta: Kedutaan Besar Amerika Serikat, Pearson Education.

Coyle, D., Hood, P., \& Marsh, D. (2010). CLIL: Content and Language Integrated Learning. Cambridge: Cambridge University Press. 
Dick, W. Carey, L., \& Carey, J.O. (2009). The Systematic Design of Instruction. Seventh Edition. Columbus, Ohio: Pearson.

Gall, M. D., Gall, J.P., \& Borg, W.R. (2003). Educational Research: An Introduction, 7th Edition. Boston: Pearson Educational, Inc.

Gay, L.R., Mills, G.E., \& Airasian, P.W. (2012). Educational Research: Competencies for Analysis and Applications 10th ed. USA: Pearson.

de Graaff, Koopman, Anikina and Westhoff Graaff, de et al. (2007). Identifying Effective L2 Pedagogy in Content and Language Integrated Learning (CLIL). Based on "An Observation Tool for Effective L2 Pedagogy in Content and Language Integrated Learning (CLIL)". The International Journal of Bilingual Education and Bilingualism, 10(5), 603624.

Graves, K. (2000). Designing Language Course: A Guide for Teachers. Boston: Heinle and Heinle Thomson Learning.

HAMKA, (2015). Tafsir Al-Azhar, Juz 1, 2, 3. Jakarta: Gema Insani.

Hidayati, E. (2014). Pengembangan Model Lingkar Sastra in Pembelajaran Apresiasi Cerita Pendek Bermuatan Nilai-Nilai Pendidikan Karakter Peserta Didik SMP/MTs. Seloka: Jurnal Pendidikan Bahasa dan Sastra Indonesia, 3(2). http://journal.unnes.ac.id/sju/index.php/seloka.

Hidayati, N. (2016). Konsep Pendidikan Islam Berwawasan Multikulturalisme Perspektif Har Tilaar. Jurnal Pendidikan Agama Islam, Program Studi Pendidikan Agama Islam, UIN SunanAmpel Surabaya, 4(1), 44-67.

Ismail, H. (2013). Kerajaan Alqur'an: Menyelami Kekuasaan Allah Ta'ala Melalui Ayat-AyatNya. Jakarta: Almahira.

Ismail, H. (2013). Mesin Waktu Alqur'an: Menyelisik Informasi dari Lauh Mahfuzh yang Terekam dalam Alqur'an. Jakarta: Almahira.

Joyce, B., Wel, M., \& Calhoun, E. (2009). Models of Teaching. Boston: Pearson Education, Inc.

Kurniasih, I., \& Sani, B. (2014). Implementasi Kurikulum 2013: Konsep dan Penerapan. Surabaya: Kata Pena.

Kurniasih, I., \& Sani, B. (2016). RagamPengembangan Model Pembelajaran. Jakarta: Kata Pena.

Nation, I.S.P., \& Macalister, J. (2010). Language Curriculum Design. New York: Routledge,

Nurkhin, A. (2014). Strategi Content and Language Integrated Learning (CLIL) untuk Meningkatkan Kualitas Pembelajaran Akuntansi Biaya. Jurnal Pendidikan Ekonomi Dinamika Pendidikan, 9(2), 130-147 http://journal.unnes.ac.id/artikel_nju/DP/4889.

Pribadi, Benny A. (2009). Langkah Penting Merancang Kegiatan Pembelajaran yang Efektif dan Berkualitas: Model Desain Sistem Pembelajaran. Jakarta: Dian Rakyat.

Purnomo, P., Zulaeha, I., \& Subyantoro. (2014). Pengembangan Buku Pengayaan Menulis Teks Eksposisi Bermuatan Nilai-Nilai Sosialuntuk SMP. Seloka: Jurnal Pendidikan Bahasa dan Sastra Indonesia, 3(2), http://journal.unnes.ac.id/sju/index.php/seloka.

Putra, N. (2012). Research and Development PenelitiandanPengembangan: SuatuPengantar. Jakarta: Grafindo Persada.

Rusman. (2014). Model-Model Pembelajaran: Mengembangkan Profesionalisme Guru. Jakarta: PT Raja Grafindo Persada. 
Sugiyono. (2015). Metode Penelitian Pendidikan (Pendekatan Kuantitatif, Kualitatif, $R$ \& D). Bandung: Alfabeta.

Suparman, M. A. (2004). Desain Instructional. Jakarta: Universitas Terbuka.

Tegeh, I.M., Jampel, I N., \& Pudjawan, K.. (201). Model Penelitian Pengembangan. Yogyakarta: Graha Ilmu.

Tomlinson, B. (ed). (2007). Developing Materials for Language Teaching. London: Continuum.

Verspoor, M.H., de Boot, K., \& Lowie, W. (2011). A Dynamic Approach to Second Language Development: Methods and Thecniques. Amsterdam/Philadhepia: John Benjamins Publishing Company.

University of Cambridge ESOL Examinations. Teaching History through English $-a$ CLIL Approach. United Kingdom: Cambridge.

Zarman, W. (2014). Membentuk GenerasiSains. Majalah Gontor, 5(12), 19-22. 